\title{
Anna Gruca
}

Uniwersytet Jagielloński, Kraków, Polska

anna.maria.gruca@uj.edu.pl

ORCID 0000-0001-6530-9779

\section{Rola polskiej książki i jej instytucji w utrzymaniu więzi międzyzaborowych w drugiej połowie XIX w.}

\author{
Abstract \\ The role of the Polish book and its institutions in maintaing relations \\ among three annexed territories Poland in the second half of \\ the $19^{\text {th }}$ century
}

In the second half of the $19^{\text {th }}$ century, when Poland was divided between three invaders, the book and its institutions were a factor that enabled contacts for people (above all: people of the Polish science and culture), who lived in three annexed territories, first of all in the maintenance of national consciousness. A special role was played by a book trade, which business was led despite the states borders (on the three annexed territories), in spite of functioning of the censorship. Printing houses led a similar activity. A retrospective and current bibliography of Polish publishing output has been prepared, irrespective of the publication places of books.

Key words: national identity - book trade in the second half of the $19^{\text {th }}$ century - bibliography in the second half of the $19^{\text {th }}$ century - printing houses in the second half of the $19^{\text {th }}$ century libraries in the second half of the $19^{\text {th }}$ century.

Słowa kluczowe: świadomość narodowa - księgarstwo w 2. połowie XIX w. - bibliografia w 2. połowie XIX w. - drukarnie w 2. połowie XIX w. - biblioteki w 2. połowie XIX w.

„Z Badań nad Książką i Księgozbiorami Historycznymi” - Udział zagranicznych recenzentów w ocenie publikacji; Stworzenie anglojęzycznej wersji wydawniczej publikacji; Digitalizacja tomów archiwalnych rocznika w celu zapewnienia otwartego dostępu do nich przez Internet oraz wdrożenie i utrzymanie cyfrowej platformy redakcyjnej - zadanie finansowane w ramach umowy nr 653/P-DUN/2019 ze środków Ministra Nauki i Szkolnictwa Wyższego przeznaczonych na działalność upowszechniającą naukę. 
Na podzielonych między trzech zaborców ziemiach polskich występowało wiele czynników, które dezintegrowały naród polski ${ }^{1}$. Zalicza się do nich przede wszystkim instytucje związane $\mathrm{z}$ aparatem państwowym, różne w poszczególnych zaborach, takie jak szkoła, wojsko, administracja. Także gospodarka poszczególnych zaborów była bardziej powiązana z gospodarką państw zaborczych niż pozostałych części ziem polskich. Procesy integracyjne utrudniała ponadto zła komunikacja między poszczególnymi zaborami, której często świadomie nie rozwijały państwa zaborcze. Oczywiście nie należy tu zapominać o celowej polityce wynaradawiania prowadzonej przez zaborców. Nie brakowało jednak czynników, które integrowały podzielone ziemie polskie. Zalicza się do nich wspólny język i kulturę, tradycję i historię. We wszystkich tych obszarach dużą rolę można przypisać książce, bez której niemożliwa byłaby łączność ludzi nauki i kultury. Dzięki książce mogły rozpowszechniać się idee, prądy literackie, wspólne dla całego narodu. Pomagała utrzymać jedność polskiej nauki, poznawać poglądy uczonych pracujących w różnych zaborach, podejmować polemiki i dyskusje naukowe. Doskonale to widać na przykładzie historii, którą w okresie zaborów zajmowali się zarówno uczeni związani z wyższymi uczelniami, jak i nauczyciele szkół średnich, a także liczna rzesza uczonych prywatnych i amatorów. Dokumentowanie ojczystej historii postrzegano jako jedną z podstaw życia narodowego. W dawnych dziejach widziano potwierdzenie wielkości i wartości narodu pozbawionego własnego państwa. Wiele uwagi poświęcano badaniu przyczyn upadku Polski. Różne stanowiska wobec tego problemu stały się podstawą powstania szkół historycznych: najpierw krakowskiej, a potem warszawskiej. W omawianym okresie powstawały też monumentalne dzieła, które traktowały ziemie polskie jako całość, takie jak Bibliografia polska Karola Estreichera, Lud Oskara Kolberga, Stownik geograficzny Królestwa Polskiego i innych ziem stowiańskich, który zawierał informacje geograficzno-historyczne o miejscowościach polskich leżących na terenie wszystkich zaborów. Rolę integracyjną odgrywały utwory popularnych pisarzy. Można tu wskazać chociażby Henryka Sienkiewicza. Jego Potop był drukowany w odcinkach w czasopismach Krakowa („Czas”), Warszawy (,Słowo”) i Poznania („Dziennik Poznański”). Dwa lata później w tych samych dziennikach ukazywał się Pan Wołodyjowski. Podobnie było z powieścią Quo vadis, która także była drukowana równocześnie w trzech zaborach.

${ }^{1}$ A. Galos, Tendencje integracyjne i dezintegracyjne na ziemiach polskich $w$ dobie popowstaniowej (do 1914 r.), [w:] Drogi integracji społeczeństwa w Polsce XIX-XX w., pod red. H. Zielińskiego, Wrocław 1976, s. 9-33. 


\section{Księgarstwo i ruch wydawniczy}

Mieczysław Rulikowski pisząc o roli księgarstwa polskiego w czasie zaborów stwierdzał, że ze względu na jego misję kulturalną „należało do tych nielicznych dziedzin życia narodowego, które poza warunkami cenzuralnymi i ekonomicznymi, mogły nie liczyć się z faktem podziału kraju"2. Powtarzając to stwierdzenie w referacie przygotowanym na pierwszy Zjazd Księgarzy w Lublinie w 1918 r. dodawał, iż ,służąc interesom całego narodu, nie chcąc i nie mogąc zacieśniać się $\mathrm{w}$ obrębie jednej dzielnicy [...] stanowiło księgarstwo jeden organizm, było księgarstwem polskim”’3. Jedność polskiego księgarstwa przejawiała się na kilku płaszczyznach. Książki wydawane na terenie jednego zaboru były obecne w asortymencie księgarń dwóch pozostałych. W autonomicznej Galicji import wydawnictw z terenu Królestwa Polskiego czy zaboru pruskiego nie napotykał w zasadzie na przeszkody. W Krakowie działała od 1886 r. filia księgarni J.K. Żupańskiego z Poznania, prowadzona przez Stefana Żupańskiego. Miała ona na składzie wydawnictwa poznańskiej księgarni, łącznie z wartościową serią „Pamiętniki z XVIII Wieku”. S. Żupański planował otworzyć filię także we Lwowie. Gdy w 1891 r. księgarnię Żupańskiego kupiła Spółka Wydawnicza Polska, nadal podtrzymywała kontakty z Poznaniem i książki publikowane przez działającą tam wciąż księgarnię pod firmą J.K. Żupańskiego, będącą już własnością Zygmunta Celichowskiego, docierały do Krakowa ${ }^{4}$.

Dystrybucja książek odbywała się też poprzez tzw. składy główne. I tak np. księgarnia Leonarda Zwolińskiego w Krakowie prowadziła skład główny na Galicję publikacji warszawskiej firmy Teodora Paprockiego. Szerokie kontakty z księgarzami wszystkich zaborów utrzymywał lwowski księgarz Adam Dominik Bartoszewicz ${ }^{5}$. Prowadził skład główny warszawskiej firmy Celsa Lewickiego i Sp. Jego wydawnictwa rozprowadzały natomiast w Warszawie m.in. księgarnie Salomona Lewentala, Ferdynanda Hoesicka, Gustawa Sennewalda. W zaborze pruskim kontakty handlowe łączyły go z firmą Żupańskiego w Poznaniu oraz Józefa Buszczyńskiego z Torunia. W „Kurierze Poznańskim” można znaleźć wiadomość o jeszcze innego rodzaju kontaktach w dystrybucji nakładów między zaborami. W grudniu 1897 r. kilkakrotnie zamieszczono

2 M. Rulikowski, Księgarstwo i czytelnictwo polskie wobec wojny, Warszawa 1915, s. 4. Powtórzył to niemal dosłownie w swoich wspomnieniach L. Fiszer. Zob. L. Fiszer, Wspomnienia starego księgarza, Warszawa 1959, s. 69.

M. Rulikowski, Księgarstwo polskie w Królestwie w czasie wojny, Warszawa 1918, s. 5.

4 A. Gruca, Wydawnictwa poznańskie w asortymencie księgarni Spółki Wydawniczej Polskiej w Krakowie (1890-1916), [w:] Kultura książki w Krakowie doby autonomii galicyjskiej. Praca zbiorowa, pod red. M. Kocójowej, Wrocław 1991, s. 49-62.

5 M. Konopka, Adam Dominik Bartoszewicz redaktor, księgarz i wydawca lwowski (18381886), Kraków 1995, s. 121-124. 
w nim ogłoszenie o zawarciu umowy ze Spółką Wydawniczą Polską w Krakowie, na mocy której można było zamawiać prenumeratę serii „Nowa Biblioteka Uniwersalna” publikowanej przez Spółkę za pośrednictwem redakcji „Kuriera”. W jednym z numerów zamieszczono wykaz tytułów wydanych w ramach serii w $1896 \mathrm{rr}^{6}$

Z kolei import książek z Galicji do Królestwa Polskiego i zaboru pruskiego utrudniała cenzura państw zaborczych. Janusz Kostecki wyliczył, iż 28\% publikacji docierających do Królestwa objętych było całkowitym zakazem cenzury. Kolportowano tu głównie książki opublikowane przez wydawców z Krakowa i Lwowa (90\%). Książki sprowadzano stosunkowo niedługo od daty opublikowania: $2 / 3$ tytułów trafiało do urzędu cenzury w roku ich wydania. Czytelnicy $\mathrm{z}$ tego terenu mieli więc dostęp do względnie aktualnej oferty wydawców galicyjskich ${ }^{7}$. Księgarnie w Królestwie Polskim dysponowały jednak ofertą znacznie szerszą niż dopuszczona przez cenzurę, ponieważ książki docierały tutaj również drogami nielegalnymi. Jak wspominał Ludwik Fiszer, księgarnia Wendego w Warszawie, w której wówczas pracował, posiadała na składzie książki niemal wszystkich wydawców galicyjskich i poznańskich. Tytuły zakazane przez cenzurę przechowywane były w specjalnym zakonspirowanym magazynie, pod lokalem księgarni. Znajdowały się tam „wszystkie ważniejsze wydawnictwa będące na indeksie, które ekspediowało się księgarzom bez faktury"8. Księgarze galicyjscy uciekali się do rozmaitych podstępów, aby książki zakwestionowane przez cenzurę pozostałych zaborów docierały jednak na te tereny. Wojciech Gottlieb pisał o ich dostarczaniu za pośrednictwem nieświadomych tego faktu księgarzy niemieckich. Przesyłano paczkę z książkami np. do Lipska, a wkrótce po tym pismo informujące o pomyłce i zawierające prośbę, aby nie rozpakowując paczki przekierowano ją do właściwej księgarni warszawskiej. Wykorzystywano tutaj fakt, iż cenzura carska nie kontrolowała książek nadchodzących z Niemiec ${ }^{9}$.

Książki wydane $w$ innych zaborach oraz na emigracji starali się sprowadzać księgarze poznańscy, choć wiązało się to, zwłaszcza w ostatniej ćwierci XIX w., z groźbą kary grzywny i więzienia wymierzaną przez władze zaborcze. Doświadczył takich represji Jan Konstanty Żupański, w którego księgarni policja przeprowadzała częste rewizje. Ich wynikiem była zazwyczaj konfiskata książek oraz kara grzywny dla księgarza. Notatki policji wskazują na rozlegle

6 Zaproszenie do przedplaty, „Kurier Poznański” 1897, t. 26, nr 298 z 31 grudnia, s. 1.

7 J. Kostecki, Publikacje importowane na rynku ksiegarskim zaboru rosyjskiego w latach 1865 1904. Z problemów geografii kontaktów, [w:] Ksiażka i prasa w systemie komunikacji społecznej. Przeszłość, dzień dzisiejszy, perspektywy, pod red. M. Judy, Lublin 2002, s. 52-54.

8 L. Fiszer, dz. cyt., s. 69.

9 W. Gottlieb, Księgarstwo małopolskie przed wojna światowa, „Przegląd Księgarski” 1933, t 9, s. 188-189. 
kontakty Żupańskiego z ośrodkami wydawniczymi w różnych częściach ziem polskich, m. in. Krakowem, Lwowem, Wadowicami, Warszawą, Wilnem ${ }^{10}$. Inny poznański księgarz, Mieczysław Leitgeber, również wykazywał się sporą aktywnością w tym zakresie. Relacje handlowe łączyły go z księgarzami w Warszawie (Michał Glücksberg), Lwowie (Karol Wild) i Krakowie (Daniel Edward Friedlein). Książki wydane na terenie Galicji rozpowszechniał też w swojej księgarni Jarosław Leitgeber. Szeroko reklamował w swoich prospektach np. serię „Nauka i Sztuka”, zaplanowaną przez Towarzystwo Nauczycieli Szkół Wyższych we Lwowie dla osób ze średnim wykształceniem, a mającą się składać z prac popularnonaukowych z zakresu historii, historii sztuki, literatury ${ }^{11}$.

Stefan Dippel w swoich pamiętnikach zwracał uwagę na jeszcze jeden fakt, będący dowodem jedności księgarstwa: wzajemną wymianę praktykantów ${ }^{12}$. Poszczególni księgarze, otwierający później własne firmy, praktykowali w renomowanych księgarniach nie tylko poza granicami kraju, ale także w różnych zaborach. Znany lwowski księgarz, Bernard Połoniecki, zanim wyjechał na praktykę do Lipska i Wiednia, pracował w księgarniach w Kielcach i Warszawie. U F. Hoesicka w Warszawie praktykował inny lwowski księgarz, Herman Altenberg. Również w Warszawie, w firmie Gebethner i Wolff, odbywał praktykę Marian Krzyżanowski zanim objął po ojcu krakowską księgarnię. Dotyczyło to także księgarzy pracujących w mniejszych ośrodkach, np. tarnowski księgarz, Józef Pisz, uczył się księgarstwa w Warszawie i Łodzi.

Utrudnienia stwarzane przez cenzurę dotykały też ruch wydawniczy ${ }^{13}$. Książki pisarzy zabronionych przez cenzurę rosyjską czy pruską ukazywały się pod pseudonimami w Galicji ${ }^{14}$. Jak pisze Janusz Dunin, „ludzie związani z tzw. ziemiami zabranymi, byłym Księstwem Litewskim, jeśli pragnęli publikować przenosili się na teren Galicji, albo wysyłali tam swoje teksty. Kraków i Lwów stały się również ważnymi centrami publikacji dla osób pochodzących z Kresów Północno-Wschodnich"15. Przytacza przykład pochodzącego

10 M. Foć, M. Romanowska, Jan Konstanty Żupański. Życie i dzieło, Poznań 1996, s. 116-117.

11 I. Kandulska, Działalność Jarosława Leitgebera - drukarza, księgarza, wydawcy i pisarza ludowego w latach 1873-1914, „Pamiętnik Biblioteki Kórnickiej” 1979, z. 15, s. 116.

12 S. Dippel, O księgarzach, którzy przeminęli, Wrocław 1976, s. 50.

13 Należy tu wspomnieć o wariantach wydawniczych - odmianach tekstu książek publikowanych w Galicji, przeznaczonych dla Królestwa Polskiego. W takiej formie ukazywały się np. niektóre tomiki popularnej serii „Biblioteka Mrówki” publikowanej we Lwowie najpierw przez A.D. Bartoszewicza, a następnie przez B. Połonieckiego. Choć za taką formą stały też względy ekonomiczne, to mimo to pozwalała ona Polakom z Królestwa - choć w okrojonej formie - korzystać z tych samych publikacji, co ich rodacy w Galicji.

14 Spółka Wydawnicza Polska w Krakowie wydała np. w 1902 r. powieść Upiory Walerego Przyborowskiego, której tłem było powstanie styczniowe, a była zabroniona przez cenzurę rosyjską.

15 J. Dunin, Losy książki polskiej w Wilnie XIX-XX wieku a jej sytuacja na terenie Galicji. (Próba ujęcia konfrontatywnego), [w:] Kraków-Lwów. Książki, czasopisma, biblioteki XIX i XX wieku. 
z Litwy A.D. Bartoszewicza, który osiedlił się we Lwowie, zakładając tam znaną księgarnię nakładową. Warszawska firma Gebethnera i Wolffa otworzyła w Krakowie swoją filię, która działała pod nazwą G. Gebethner i Sp. Umożliwiała ona nie tylko rozpowszechnianie nakładów na terenie Galicji, ale także publikowanie tych wydawnictw, które ze względu na cenzurę nie mogły się ukazać w Warszawie. Aleksander Nowolecki po powstaniu styczniowym musiał opuścić Warszawę i odtąd działalność wydawniczą i księgarską prowadził w Krakowie ${ }^{16}$.

Książki polskie były szeroko kolportowane na Górnym Śląsku. Maria Kalczyńska wymienia wśród firm księgarskich i wydawniczych utrzymujących na przełomie XIX i XX w. kontakty z Górnym Śląskiem, także wiele spoza zaboru pruskiego, m.in. pochodzące z Cieszyna, Krakowa, Lwowa, Warszawy, Wilna ${ }^{17}$. Mimo zakazów cenzury i konfiskat jakie spotykały polskie książki, nieprzerwanie dostarczane były one na Śląsk, ,,a policja nie była w stanie wytropić wszystkich, a tym bardziej poddać je procesom sądowym"18. Zasoby krakowskich druków obecnych w śląskich bibliotekach różnego typu w omawianym okresie scharakteryzowała Anna Tokarska ${ }^{19}$.

Inicjatywy wydawnicze, jednoczące Polaków z różnych zaborów, podejmowane były nie tylko przez księgarzy-nakładców. Należy przede wszystkim wspomnieć o roli Akademii Umiejętności, utworzonej w Krakowie w 1872 r., która starała się objąć swoją opieką sprawy nauki całego narodu. Ponieważ rząd austriacki nie zapewnił Akademii dostatecznych środków na realizację statutowych zadań, jej egzystencja była możliwa dzięki ofiarności społeczeństwa. Z pomocą samorzutnie pospieszyli Polacy ze wszystkich zaborów oraz przebywający na emigracji. Najwięcej ofiarodawców na początku istnienia Akademii pochodziło z zaboru rosyjskiego. Fundusze te pozwalały nie tylko na stanowienie stypendiów, nagród naukowych, ale też szeroko rozwiniętą działalność wydawniczą. Nakładem Akademii ukazywały się prace uczonych polskich z różnych zaborów. Akademia organizowała ponadto ekspedycje badawcze na tereny innych zaborów w celu zbierania materiałów do swoich wydawnictw ${ }^{20}$.

\footnotetext{
T. 5, pod red. J. Jarowieckiego, Kraków 2001, s. 38.

16 M. Kocójowa, Geneza księgarni, działalność i exodus z Warszawy Aleksandra Nowoleckiego, „Roczniki Biblioteczne” 1980, t. 24, z. 1, s. 298-299.

17 M. Kalczyńska, Drogi rozchodzenia się ksiażki polskiej na Górnym Śląsku na przełomie XIX i XX wieku, „Studia Bibliologiczne” 1998, t. 11, s. 29-30.

18 Tamże, s. 25.

19 A. Tokarska, Ksiażki, ludzie, idee. Kontakty kulturalne Górnego Śląska z Krakowem w dobie niewoli narodowej, Katowice 2003, s. 24-38.

20 Jedną z pierwszych była odbyta w 1874 r. podróż Stanisława Smolki związana z kwerendą w archiwach Prus, Pomorza i Wielkopolski dla potrzeb trzeciego tomu Monumenta Poloniae Historica. Kolejną podróż naukową odbył O. Kolberg na tereny Mazur. W jej wyniku powstał jeden
} 
Akademia Umiejętności od początku swojego istnienia czyniła starania o rozpowszechnianie swoich wydawnictw również poza granicami Galicji. Początkowo zajmowała się tym w Warszawie firma Gebethnera i Wolffa, a w Poznaniu księgarnia M. Leitgebera ${ }^{21}$. W 1891 r. Akademia zerwała poprzednie umowy i zawarła nową z księgarnią Spółki Wydawniczej Polskiej, która od tej pory miała jako jedyna prowadzić ekspedycję wydawnictw zarówno na terenie Galicji, jak i innych ziem polskich oraz za granicę. Występowały jednak trudności z rozpowszechnianiem wydawnictw Akademii na terenie Królestwa - księgarnia Gebethnera i Wolffa odmówiła podjęcia się tego zadania. Zgodziła się natomiast na pośredniczenie w przekazywaniu wydawnictw Akademii jej członkom i współpracownikom komisji z terenu Królestwa ${ }^{22}$. W następnych latach nie rezygnowano jednak z prób rozpowszechniania publikacji własnych na tym terenie. Powodzeniem cieszyły się zwłaszcza wydawnictwa historyczne, pamiętniki, teksty literackie, prace dotyczące dziejów literatury, np. w 1908 r. księgarnia Gebethnera i Wolffa sprzedała 149 egzemplarzy Pamiętników Ignacego Domeyki, a rozprawy Tadeusza Korzona Dzieje wojen i wojskowości w Polsce zamówiła aż 200 egzemplarzy ${ }^{23}$.

Koncepcje wydawnicze rodziły się również podczas zjazdów historycznych i historyczno-literackich organizowanych przez Akademię, w których brali udział uczeni ze wszystkich zaborów. Pierwszy zjazd historyków polskich zorganizowano w $1880 \mathrm{r}$. dla uczczenia czterechsetnej rocznicy śmierci Jana Długosza. Wzięli w nim także udział przybysze z Poznańskiego i Pomorza oraz kilku uczestników z Królestwa. Zjazd upłynął pod znakiem dyskusji nad koniecznością podjęcia prac nad wydawnictwami źródłowymi do historii Polski. Kolejne odbyły się w 1890 i w 1900 r., również z udziałem uczonych spoza Galicji. Natomiast pierwszy zjazd historycznoliteracki miał miejsce w 1880 r., z okazji 300. rocznicy śmierci Jana Kochanowskiego, a kolejny w 1884 r. Zjazd ten miał wytyczyć kierunki prac historycznoliterackich oraz program wydawniczy tekstów literackich. Realizacją tych postulatów było rozpoczęcie wydawania w 1889 r. serii „Biblioteka Pisarzów Polskich”, która miała popularyzować zabytki literatury polskiej, głównie z XVI w. Poszczególne tomy przygotowywali do druku także uczeni spoza Galicji, np. Z. Celichowski, czy Jan Karłowicz.

z tomów Ludu, którego wydanie finansowała Akademia. Zob. W. Bieńkowski, Kraków a Warmia i Mazury w XIX i XX wieku. Kontakty naukowe oraz zwiazki kulturalne, „Rocznik Olsztyński” 1975, t. 11, s. $75-76$.

21 K. Stachowska, Starania Polskiej Akademii Umiejętności o upowszechnianie własnych nakładów wydawniczych w latach 1873-1952, „Rocznik Biblioteki Polskiej Akademii Nauk w Krakowie", 1969, t. 15, s. 28.

22 Tamże, s. 35.

23 Tamże, s. 40-42. 
Na kolejny zjazd, im. Mikołaja Reja w 1906 r. $^{24}$, Akademia przygotowała okolicznościowe wydawnictwa, m.in. pięknie wydane Zwierciadto Reja oraz monografię Aleksandra Brücknera poświęconą pisarzowi. Podczas obrad podkreślano m.in. doprowadzenie do wydania wielu pomnikowych edycji źródłowych, co było realizacją postulatów pierwszego zjazdu z $1880 \mathrm{r}$.

Nie tylko Akademia Umiejętności organizowała zjazdy, które dawały okazję do spotkań uczonych ze wszystkich zaborów, a ich rezultatem była nie tylko wymiana myśli, pokazanie jedności polskiej nauki, ale także wydawnictwa okolicznościowe oraz będące realizacją pozjazdowych postanowień. Ważną rolę odgrywały zjazdy lekarzy i przyrodników organizowane od 1869 r. ${ }^{25}$ Pierwszy odbył się w Krakowie z inicjatywy Józefa Dietla i miał charakter międzyzaborowy. Podobne spotkania, choć już nie tak systematycznie, organizowały inne środowiska zawodowe, np. technicy, górnicy i hutnicy, dziennikarze, pedagodzy ${ }^{26}$. Po większości z nich pozostawały wydawnictwa okolicznościowe, będące wyrazem jedności poszczególnych środowisk w podzielonym przez zaborców kraju.

\section{Obchody jubileuszowe i uroczystości patriotyczno-religijne}

Jako czynniki sprawcze ruchu wydawniczego, a zarazem wydarzenia jednoczące Polaków ze wszystkich zaborów, można wskazać uroczystości i jubileusze patriotyczno-religijne. Miały miejsce we wszystkich dzielnicach, jednak zasłynął z nich przede wszystkim Kraków ${ }^{27}$. Obywały się one z okazji rocznic ważnych wydarzeń historycznych, jak 200-lecie odsieczy wiedeńskiej (1883), 100-lecie Konstytucji 3 maja (1891), 100-lecie powstania kościuszkowskiego (1894), 600-lecie odnowienia Uniwersytetu Jagiellońskiego (1900), 500-lecie zwycięstwa pod Grunwaldem (1910). Były urządzane z okazji rocznic związanych z wybitnymi Polakami: 400-lecia urodzin Mikołaja Kopernika (1873), 50-lecia pracy literackiej Józefa Ignacego Kraszewskiego (1879), 100-lecia urodzin Adama Mickiewicza (1898), 100-lecia urodzin Juliusza Słowackiego (1909). Wiązały się również z pogrzebami wybitnych osób, jak powtórny pogrzeb Kazimierza Wielkiego (1868), sprowadzenie zwłok A. Mickiewicza

24 Termin zjazdu, który zbiegł się z wypadkami strajkowymi w 1905 r., przesuwano dwukrotnie, aby umożliwić uczestnictwo w nim także uczonych z Królestwa. Przybyli oni rzeczywiście licznie, a obradom przewodniczył z ich ramienia Tadeusz Korzon. Zob. J. Hulewicz, dz. cyt., s. 143.

25 J. Cabaj, ,Jesteśmy $i$ być chcemy”. Z organizacji i statystyki zjazdów międzyzaborowych polskich środowisk medycznych i przyrodniczych, 1869-1914, część 1., „Kwartalnik Historii Nauki i Techniki" 2004, t. 49, nr 3/4, s. 135-156.

26 Tenże, Zjazdy międzyzaborowe polskich środowisk naukowych i społeczno-zawodowych w latach 1969-1914, część 2., „Kwartalnik Historii Nauki i Techniki” 2005, t. 50, nr 1, s. 51-78.

27 B. Wilk, Uroczystości patriotyczno-religijne $w$ Krakowie w okresie autonomii galicyjskiej (1860-1914), Kraków 2006. 
na Wawel (1891). Stanowiły okazję do rozpowszechniania wiedzy na temat wydarzeń historycznych, budzenia poczucia dumy z przynależności do narodu polskiego i wielkości państwa oraz z jego wybitnych przedstawicieli. Było ono stymulowane nie tylko poprzez uczestnictwo w tych obchodach, ale również poprzez wydawnictwa okolicznościowe: rozprawy naukowe, dzieła literackie, prezentujące wydarzenia czy postacie historyczne ${ }^{28}$. Niektóre z nich ukazywały się w olbrzymich jak na ówczesne czasy nakładach, np. wydane z okazji 200-lecia odsieczy wiedeńskiej Wspomnienie o Janie III Sobieskim królu polskim Stanisława Tarnowskiego opublikowane zostało w nakładzie 25 tysięcy egzemplarzy przez Gminę Miasta Krakowa i przeznaczone do bezpłatnego rozdawania wśród uczestników obchodów ${ }^{29}$. Podobnie było z okazji innych uroczystości: dbano, aby biorący w nich udział, często przybysze z odległych miejscowości, leżących poza Galicją, mogli się zaopatrzyć w okolicznościowe publikacje. Jeśli nie rozdawano ich bezpłatne, to ceny niektórych z nich były bardzo niskie, tak aby były dostępne dla jak najszerszego grona. Tak np. wydana z okazji obchodów 100-lecia powstania kościuszkowskiego broszura $\mathrm{O} n \mathrm{n}$ czelniku Kościuszce w setna rocznicę zwycięstwa pod Ractawicami autorstwa Kaspra Wojnara kosztowała pięć centów, a opublikowane z tej samej okazji Pieśni narodowe staraniem młodzieży na pamiatkę setnej rocznicy bohaterstwa ludu polskiego wydane - cztery centy. Obie publikacje wydano w olbrzymich nakładach: pierwsza miała dwa wydania - łącznie 20 tysięcy egzemplarzy, a drugiej ukazało się w sumie aż 32 wydania ${ }^{30}$.

Przybysze z innych zaborów wywozili więc z Krakowa nie tylko wrażenia, ale i wydawnictwa okolicznościowe, które mogli przekazywać tym rodakom, którzy nie mogli wziąć udziału w tych uroczystościach ${ }^{31}$.

Okazją do zaopatrywania się w książki były też pielgrzymki mieszkańców z zaborów pruskiego i rosyjskiego do Krakowa, gdzie rozwinął się kult świętych, zwłaszcza św. Stanisława ${ }^{32}$. Ich uczestnicy które zabierali rodzinnych

28 W. Bieńkowski, Krakowskie wydawnictwa obchodów kościuszkowskich w 1894 roku, „Studia Bibliologiczne" 1995, t. 9, s. 164-171.

29 Tenże, Wydawnictwa obchodu dwustulecia odsieczy wiedeńskiej w 1883 r. i ich rejestracja bibliograficzna, [w:] Kultura ksiązki w Krakowie..., s. 22.

30 W. Bieńkowski, Obchody kościuszkowskie w Krakowie w 1894 roku, [w:] Kraków w powstaniu kościuszkowskim, red. J.M. Małecki, Kraków 1996, s. 129-130.

31 Na granicach dokonywano kontroli uczestników patriotycznych uroczystości. Szczególnie dotykało to Ślązaków, np. powracających po obchodach grunwaldzkich w 1910 r. poddano na granicy w Mysłowicach szczegółowej kontroli. Oprócz kilku sztandarów i ozdób narodowych skonfiskowano, książki, śpiewniki, okolicznościowe wydawnictwa, ulotki, karty pocztowe.

32 Szczególnie chętnie pielgrzymowali do Krakowa z okazji świąt religijnych Ślązacy. Od 1870 r. w czasie Zielonych Świątek organizowane były pielgrzymki przez redakcje śląskich czasopism: „Katolika”, „Gazety Opolskiej”, „Nowin Raciborskich”. W pierwszej wzięło udział 800 osób. Pielgrzymki były okazją do edukacji patriotycznej ich uczestników. Miały charakter patriotycznej demonstracji przeciw zaborcom. Przed każdą powstawał w Krakowie komitet, który opracowywał 
miejscowości nie tylko książki religijne, lecz także tomiki wierszy Marii Konopnickiej, polskie wydawnictwa patriotyczne z utworami różnych autorów ${ }^{33}$. U schyłku lat 80 XIX w. nasiliły się pielgrzymki Górnoślązaków do Kalwarii Zebrzydowskiej i Alwerni, które trwały do wybuchu I wojny. Niektóre oficyny wydawnicze, np. Foltynów w Wadowicach nastawione były na obsługę ruchu pielgrzymkowego, publikując modlitewniki i różnego rodzaju druki pamiątkowe. Także pielgrzymki do Częstochowy były dla Ślązaków źródłem zaopatrywania się w polskie książki. Na potrzeby pielgrzymów pracowała tu drukarnia paulinów. Książkom religijnym przywożonym z pielgrzymek lub dostarczanym do księgarni śląskich przez wyspecjalizowane drukarnie częstochowskie przypisuje się w wielu przypadkach rolę pierwszego podręcznika języka polskiego dla ludności śląskiej ${ }^{34}$.

\section{Rejestracja bibliograficzna}

Duże znaczenie dla pokazania piśmiennictwa polskiego powstającego w poszczególnych zaborach jako całości wytworzonej przez polski naród miała rejestracja bibliograficzna. Oczywiście należy tu w pierwszej kolejności wymienić Bibliografię polska K. Estreichera, obejmującą XIX stulecie. Wiadomo, że Estreicher podjął się tej gigantycznej pracy z przyczyn patriotycznych. Wspominał o tym we wstępach do poszczególnych tomów. Jak pisał jego wnuk: „W pierwszym rzędzie autorzy Bibliografii chcą pokazać rozmiary tej kultury, udokumentować jej znaczenie i to zarówno w wieku XIX, jak i w wiekach poprzednich. W okresie ucisku po powstaniu styczniowym szło dziadkowi o podtrzymanie na duchu prześladowanych..." ${ }^{35}$. Bibliografia objęła swoim zasięgiem terytorialnym całość polskich ziem. Estreicher chciał bowiem pokazać, że mimo przynależności poszczególnych części ziem polskich do państw zaborczych piśmiennictwo polskie powinno się traktować jako całość i dopiero wówczas może być porównywane pod względem liczbowym z produkcją wydawniczą innych krajów. Charakterystyczna była jego dążność do rejestrowania nawet najdrobniejszych druków, łącznie z dojutrkami - jak nazywał dokumenty życia społecznego, które mogły według niego świadczyć o ważnych wydarzeniach. To również wynikało z pobudek patriotycznych, chęci pokazania bogactwa piśmiennictwa polskiego. Materiały do bibliografii czerpał Estreicher ze zbiorów bibliotek w poszczególnych zaborach. Wykorzystał katalogi Biblioteki Ossolineum, Biblioteki Szkoły Głównej Warszawskiej i Biblioteki Jagiellońskiej.

\footnotetext{
program dla pielgrzymów.

3 M. Pater, Polskie dążenia narodowe na Górnym Ślasku (1891-1914), Wrocław 1998, s. 238.

M. Kalczyńska, dz. cyt., s. 20.

35 Cytat za J. Korpała, Karol Estreicher [st.] twórca „Bibliografii polskiej”, Wrocław 1980, s. 221 .
} 
W drugiej połowie XIX w. pojawiły się też pierwsze próby bieżącej rejestracji polskiego piśmiennictwa. Dużą rolę odegrali tu księgarze, którym przestały już wystarczać katalogi poszczególnych firm i w związku z tym rozpoczęli publikowanie czasopism bibliograficznych. Pierwsze z nich, wydawane m.in. przez Feliksa Frankego we Lwowie, Jakuba Żegotę Wywiałkowskiego w Krakowie, M. Leitgebera w Poznaniu, Stanisława Czarnowskiego w Warszawie, czy A.D. Bartoszewicza we Lwowie, nie ukazywały się zazwyczaj długo ${ }^{36}$. Systematyczną rejestrację bieżącej produkcji wydawniczej rozpoczą dopiero „Przewodnik Bibliograficzny”, miesięcznik założony w Krakowie w lipcu 1878 r. przez Władysława Wisłockiego, kustosza Biblioteki Jagiellońskiej. Redakcja dokładała starań, aby pismo objęło swoim zasięgiem całość polskiej produkcji wydawniczej. W 1901 r. w Warszawie zaczęło się ukazywać inne ważne czasopismo bibliograficzne - miesięcznik „Książka”. Również i to pismo dawało przegląd nie tylko nowości wydanych przez firmy warszawskie, ale także w innych zaborach. Zawierało ponadto część krytyczną z recenzjami publikacji z różnych dziedzin wiedzy oraz literatury pięknej. Zarówno „Przewodnik Bibliograficzny” (od 1880 r.) jak i „Książka” miały kronikę informującą o wydarzeniach związanych z książką: nowościach wydawniczych, działalności firm księgarskich i drukarskich, o bibliotekach w różnych zakątkach ziem polskich, bez względu na przynależność państwową, o zasobach i nowych nabytkach Biblioteki Jagiellońskiej. Dzięki temu uczeni z pozostałych zaborów zyskiwali orientację odnośnie interesujących ich dzieł, rękopisów, starodruków.

Należy podkreślić ponadto rolę bieżącej informacji bibliograficznej w postaci ogłoszeń w prasie danego zaboru, a dotyczących nowości wydawniczych opublikowanych w innych zaborach ${ }^{37}$. Świadectwem kontaktów międzyzaborowych są również katalogi księgarskie i wydawnicze, w których podawano ceny książek w walutach poszczególnych państw zaborczych. Ukazywały się

\footnotetext{
36 J. Korpała, Dzieje bibliografii w Polsce, Warszawa 1969, s. 180-182.

37 Pokazuje to np. Zofia Byczkowska na przykładzie reklamy książek beletrystycznych na łamach wydawanych w Warszawie czasopism „Zorza” i „Gazeta Świąteczna”. W obu pismach dominowały reklamy książek opublikowanych na terenie Królestwa Polskiego, ale pojawiały się też ogłoszenia dotyczące wydawnictw galicyjskich i z zaboru pruskiego. Podobne zjawisko zaobserwowała Krystyna Heska-Kwaśniewicz analizując promocję polskiej książki w „Zaraniu Śląskim”. Tu w dziale „Najpoczytniejsze książki polskie” zamieszczano m.in. obszerne informacje o utworach Wyspiańskiego, opublikowanych w Krakowie. W śląskich czasopismach podawano informacje o drukach, których kolportażu zakazano, co było zapewne dobrą dla nich reklamą. Wiele miejsca wydarzeniom z krakowskiego świata książki poświęcała „Gazeta Kaliska”. Zob. Z. Byczkowska, Popularyzacja ksiażek beletrystycznych w czasopismach ludowych Królestwa Polskiego w latach 1866-1898, „Pamiętnik Biblioteki Kórnickiej” 1891, z. 18, s. 123-149; M. Kalczyńska, dz. cyt., s. 24-25; D. Wańka, Krakowski świat ksią̇ki w , Gazecie Kaliskiej” (1893-1914), [w:] Kraków Lwów. Ksiązki - czasopisma-biblioteki XIX i XX wieku. T. 2, pod red. H. Kosętki, B. Góry, E. Wójcik, s. 110-120. K. Heska-Kwaśniewicz, Promocja ksiązki polskiej na łamach „Zarania Śląskiego” w latach 1907-1912, [w:] Książa polska na Śląsku 1900-1922. Zarys problematyki, pod red. M. Pawłowiczowej, Katowice 1993, s. 91-97.
} 
też katalogi i prospekty przeznaczone specjalnie dla odbiorców z innych zaborów. Dwa takie katalogi wydała np. krakowska Spółka Wydawnicza Polska. $\mathrm{W}$ jednym z nich, prezentującym księgarzom zaboru pruskiego serię „Nowa Biblioteka Uniwersalna", sugerowano, że łatwiej jest przemycać przez granicę pojedyncze arkusze niż oprawione już tomy. Drugi wydany był z myślą o odbiorcach z zaboru rosyjskiego i zawierał wykaz zabronionych przez cenzurę książek wydanych nakładem Spółki. O takich wydawnictwach informowano zresztą i w innych katalogach tej firmy. Z kolei poznańska księgarnia M. Leitgebera i Spółki opublikowała prospekt serii „Biblioteka Najcelniejszych Utworów Europejskich", wydawanej przez S. Lewentala w Warszawie, którą przyjęła na skład główny. Oprócz informacji interesujących ogół czytelników, bez względu na przynależność państwową, podano tu warunki prenumeraty na terenie zaboru pruskiego i Niemiec.

\section{Drukarnie}

Łączność między zaborami pomagały utrzymać również drukarnie, które pracowały na zlecenie wydawców pochodzących z różnych zaborów. W drugiej połowie XIX w. dominująca pozycję zaczęły zajmować drukarnie krakowskie, które wyróżniały się jakością oferowanych usług. O poziom wykonywanych tutaj druków dbali kierownicy artystyczni, którymi w poszczególnych drukarniach byli znani ówcześni artyści. Jak pisał w swoich pamiętnikach Ludwik Fiszer, o wyższości krakowskich zakładów nad warszawskimi decydował dodatkowo fakt, że miały one zawsze na składzie zapasy różnych gatunków papieru i był on tańszy niż w Warszawie. Tak więc np. Drukarnia W.L. Anczyca i Sp. wykonywała zamówienia księgarzy warszawskich, m.in. Michała Arcta, F. Hoesicka, Jakuba Mortkowicza, księgarni Edwarda Wendego i Spółki. Drukowała także wydawnictwa Kasy im. Mianowskiego ${ }^{38}$. Klientów z różnych zaborów miała też Drukarnia Narodowa, kierowana przez doskonałego fachowca - Napoleona Telza. Z Warszawy tłoczyły w niej swoje nakłady księgarnie Gabriela Centnerszwera, Józefa Fiszera, Jakuba Mortkowicza, E. Wendego i Spółki, a z Łodzi - Rudolfa Wegnera.

Drukarnie pracowały przede wszystkim na zlecenie różnych nakładców, ale też same prowadziły bardziej lub mniej rozwiniętą działalność wydawniczą ${ }^{39}$. Publikowały dzieła naukowe, podręczniki, literaturę piękną. Wśród nakładów własnych drukarń krakowskich na uwagę zasługują wydawnictwa okolicznościowe, publikowane z okazji różnych uroczystości odbywających

38 H. Broda, Działalność drukarska i bibliofilska Wacława Anczyca, „Roczniki Biblioteczne” 1979 , t. 23, s. 135.

39 A. Gruca, Działalność wydawnicza drukarń krakowskich w okresie autonomii galicyjskiej, [w:] Ludzie i książki. Studia i szkice bibliologiczno-biograficzne, red. E. Andrysiak, Łódź 2011, s. 135-146. 
się w Krakowie: 200. rocznicy odsieczy wiedeńskiej, 100. rocznicy Konstytucji 3 maja, 100. rocznicy powstania kościuszkowskiego, uroczystości złożenia zwłok A. Mickiewicza na Wawelu i 100-lecia jego urodzin, 50-lecia pracy literackiej J.I. Kraszewskiego. Wydawnictwa takie, nabywane przez uczestników tych uroczystości z innych zaborów, miały szansę dotrzeć do wszystkich zakątków ziem polskich.

Drukarze, podobnie jak księgarze, praktykowali w zakładach położonych w różnych zaborach. I tak np. Józef Filipowski, późniejszy zarządca Drukarni Uniwersytetu Jagiellońskiego, uczył się zawodu m.in. w drukarni J. Buszczyńskiego w Toruniu, a inny znakomity drukarz krakowski, Józef Łakociński, zanim objął kierownictwo Drukarni „Czasu”, pracował w firmach warszawskich: Józefa Ungra i Józefa Bergera. Natomiast Berger, który był również księgarzem, praktykował u Ambrożego Grabowskiego w Krakowie. Łakociński, który cieszył się w środowisku drukarskim dużym poważaniem, w swoim liście do publikowanego we Lwowie „Przewodnika dla Spraw Drukarsko-Litograficznych” apelował, aby zecerzy doskonalili się w języku polskim nie tylko, by nie przysparzać pracy korektorom. Uważał, że powinni oni stać się „częścią tej armii, która broni swej mowy ojczystej i stara się uchronić ją od skażenia i obcych naleciałości” ${ }^{40}$.

\section{Biblioteki}

Książki publikowane w różnych miejscowościach ziem polskich trafiały do bibliotek w poszczególnych zaborach. Jednak nie w każdym z nich właściciel księgozbioru mógł włączać legalnie do niego wszystkie interesujące go książki. Tadeusz Epsztein charakteryzując księgozbiory polskiego ziemiaństwa na Ukrainie, w zaborze rosyjskim, wspominał o kontrolach zawartości bibliotek przez carskich urzędników, poszukujących zakazanej literatury. Nie znaczy to, że takiej literatury w tych księgozbiorach nie było. Właściciele bibliotek albo sami przemycali zakazane książki przez granicę przewożąc je w specjalnych skrytkach, czy wszyte w ubraniu, albo korzystali z pomocy żydowskich kupców, którzy „chcąc i tu dobrze zarobić, szwarcowali przez granicę w Brodach pod chałatami wszelkie zakazane druki”, jak wspominała Maria Kopernicka w swoich pamiętnikach ${ }^{41}$. Docierały one do czytelników również przy pomocy bibliotek wędrownych, które upowszechniły się w drugiej połowie XIX w. ${ }^{42}$

40 J. Łakociński, [List do Redakcji], ,Przewodnik dla Spraw Drukarsko-Litograficznych” 1889, t. 1 , s. 91 .

${ }^{41}$ Cyt. za T. Epsztein, Z piórem i paleta. Zainteresowania intelektualne i artystyczne ziemiaństwa polskiego na Ukrainie w II polowie XIX w., Warszawa 2005, s. 64.

42 Tamże, s. 65; T. Epsztein, Biblioteki wędrowne w dworach ziemiańskich na Lubelszczyźnie w XIX i XX wieku, [w:] Ziemiaństwo na Lubelszczyźnie. Materiaty II sesji naukowej zorganizowa- 
Biblioteki prywatne tworzone w różnych zaborach zazwyczaj nastawione były nie tylko na zaspakajanie potrzeb ich właścicieli. Wiele z nich miało wyraźny program gromadzenia i udostępniania zbiorów, skierowany na chronienie i dokumentowanie dorobku kulturalnego i naukowego narodu, z myślą przekazania późniejszym pokoleniom spuścizny narodowej. Dotyczyło to zwłaszcza bibliotek wielkoziemiańskich, które nie tylko gromadziły cenne zbiory, ale też stawały się warsztatem pracy uczonych z różnych zaborów. Dobrym przykładem jest Biblioteka Kórnicka. Realizowała ona, podobnie jak biblioteka Poznańskiego Towarzystwa Przyjaciół Nauk, kwerendy uczonych spoza Wielkopolski. Prowadziła ponadto wypożyczanie zbiorów do różnych miejscowości, także w innych zaborach. Cenne rękopisy kórnickie wędrowały do Krakowa i Lwowa wykorzystywane tam do prac edytorskich ${ }^{43}$. Spośród instytucji najczęściej wypożyczała je Akademia Umiejętności, m.in. dla Stanisława Windakiewicza, Tadeusza Grabowskiego, Jana Łosia, Stanisława Kutrzeby ${ }^{44}$. Ze zbiorów kórnickich drogą wypożyczeń do miejsca zamieszkania korzystali też m.in. K. Estreicher, Teodor Wierzbowski, Oswald Balzer ${ }^{45}$. Kierujący Biblioteką Kórnicką Z. Celichowski odpowiadał na liczne kwerendy napływające od uczonych z różnych stron ziem polskich, m.in. od Aleksandra Kraushara, Klemensa Kanteckiego. Ale i bibliotekarze Biblioteki Kórnickiej otrzymywali tą drogą informacje z innych bibliotek, tak jak Wojciech Kętrzyński podczas pracy nad kolejnym tomem Acta Tomiciana, który nie mógł osobiście korzystać z bibliotek warszawskich ze względu na swój udział w powstaniu styczniowym. Z kolei po przeniesieniu się do Lwowa służył pomocą w poszukiwaniu informacji do tego wydawnictwa w zbiorach Ossolineum ${ }^{46}$.

Narastanie zbiorów bibliotek prywatnych zależało często od zasobności właściciela. Natomiast w przypadku bibliotek instytucjonalnych należy zwrócić uwagę na zjawisko mecenatu społecznego, mającego charakter ponadzaborowy. Dzięki darom bogaciły się zbiory biblioteki utworzonej w $1856 \mathrm{r}$. przy Towarzystwie Naukowym Krakowskim, która później stała się biblioteką Akademii Umiejętności. Akademia miała niewielkie fundusze na pomnażanie zbiorów bibliotecznych, stąd też powiększały się one głównie dzięki ofiarodawcom pojedynczych książek czy całych księgozbiorów, pochodzącym z różnych części ziem polskich. Wartościowy dar rękopisów i gazet wileńskich pochodził np. od Stanisława Filipa Krzyżanowskiego, ziemianina z Ukrainy.

nej w Muzeum Zamoyskich w Kozłówce 22-24 maja 2002, oprac. R. Maliszewska, Kozłówka 2003, s. $555-561$.

43 A. Mężyński, Biblioteka Kórnicka Jana Dziatyńskiego, „Pamiętnik Biblioteki Kórnickiej” 1976, z. 12, s. 128.

44 D. Zagartowska, Bibliotekarz, „Pamiętnik Biblioteki Kórnickiej” 1996, z. 24, s. 29.

45 Tamże, s. 30.

46 B. Kosmanowa, Biblioteki polskie w Wielkim Księstwie Poznańskim, Poznań 1982, s. 188-189. 
Inny cenny księgozbiór złożony z ponad dziesięciu tysięcy dzieł, rękopisów, map, rycin, biblioteka otrzymała po śmierci znanego warszawskiego bibliografa i bibliofila, Cypriana Walewskiego, od jego brata ${ }^{47}$.

Również dla powstałej w 1857 r. Biblioteki Poznańskiego Towarzystwa Przyjaciół Nauk dary były podstawowym źródłem powiększania księgozbioru. Płynęły one z różnych środowisk, także spoza terenu zaboru pruskiego. Były to zarówno pojedyncze książki i rękopisy, często unikatowe, jak i cale księgozbiory ${ }^{48}$. Tę niezwykłą ofiarność autorka historii biblioteki, Aniela Koehlerówna, przypisuje zrozumieniu przez społeczeństwo, iż Towarzystwo stanowiło „bastion obronny przeciw zakusom germanizacji, że toczy się tu w sposób swoisty patriotyczna walka o zachowanie poczucia narodowego wśród Polaków w zaborze pruskim"49.

Także Biblioteka Jagiellońska pozyskiwała cenne nabytki od osób prywatnych. Pragnęły one w ten sposób poprzeć ideę bibliotheca patria, którą kierował się K. Estreicher, jej dyrektor od 1868 r. Chciał on uczynić z Biblioteki Jagiellońskiej polską bibliotekę narodową, służącą nie tylko potrzebom Uniwersytetu Jagiellońskiego. Dlatego szczególnie dbał o powiększanie zbioru polskich książek. Biblioteka posiadała wprawdzie prawo do egzemplarza obowiązkowego, na mocy ustawy z 1862 r., a od 1888 r. otrzymywała także druki skonfiskowane na terenie Galicji Zachodniej, jednak te źródła nie wystarczały do realizacji wyznaczonych przez Estreichera celów, a fundusze na zakupy były niewielkie. Bibliotekę wspomagały więc dary. Zestawiony spis ofiarodawców z tego okresu objął 330 nazwisk, a były wśród nich osoby ze wszystkich zaborów ${ }^{50}$. Do większych darów należał liczący ok. cztery i pół tysiąca księgozbiór prawniczy Romualda Hubego, profesora w Petersburgu i Warszawie, kolekcja Mariana Gallego, lekarza i kolekcjonera z Żytomierza. Bibliotekę zasilali darami także księgarze, nie tylko galicyjscy. Wśród ofiarodawców znaleźli się: Adam Zawadzki z Wilna, Józef Chociszewski z Chełmna, M. Glücksberg i G. Sennewald z Warszawy, Karol Miarka z Mikołowa, a także księgarze i wydawcy pracujący poza granicami ziem polskich: Jan Nepomucen Bobrowicz z Lipska, Eustachy Januszkiewicz z Paryża. Dzięki takim działaniom zbiory działu polskiego zwiększyły się trzykrotnie, a Biblioteka Jagiellońska na przełomie XIX i XX w. stała się najzasobniejszą polską książnicą i najlepiej zaopatrzoną w polonika.

47 D. Rederowa, Z. Jabłoński, Zarys dziejów Biblioteki PAN w Krakowie w latach 1856-1956, „Rocznik Biblioteki Polskiej Akademii Nauk w Krakowie” 1957, t. 1, s. 18.

48 A. Koehlerówna, Biblioteka Poznańskiego Towarzystwa Przyjaciót Nauk 1857-1957, „,Roczniki Historyczne" 1957, t. 23, s. 387-391.

49 Tamże, s. 386.

50 W. Berbelicki, Dary dla Biblioteki Jagiellońskiej w l. 1868-1904, „Biuletyn Biblioteki Jagiellońskiej” 1959, t. 11, nr 1-2, s. 62-63. 
Dary, choć nie brak było wśród nich cennych pozycji, powodowały także narastanie w bibliotekach dubletów. Biblioteki, które je posiadały, prowadziły wymianę z innymi, bez względu na ich lokalizację. I tak np. Biblioteka PTPN wydała drukowany wykaz dubletów, z których najwięcej pozyskała Biblioteka Jagiellońska ${ }^{51}$. Wymianę międzyzaborową prowadzili także właściciele prywatnych bibliotek. Bogumiła Kosmanowa cytuje wypowiedź Włodzimierza Dzieduszyckiego na ten temat:

„Mój śp. Ojciec Józef Dzieduszycki zbierał książki polskie i trudnił się bibliografią naszą równocześnie ze swoim szwagrem i siostrzeńcem śp. Tytusem Działyńskim. Mój Ojciec stworzył bibliotekę u siebie w Poturzycy (Galicja), jak mój Wuj składał takową w Kórniku. Porozumieli się ze sobą i bardzo często zmiany robili..." ${ }^{52}$. W tej wymianie brały też udział księgarnie. Tak było w przypadku Biblioteki Kórnickiej, która współpracowała nie tylko z firmami poznańskimi, ale także warszawskimi (Gebethner i Wolff) i krakowskimi (Aleksandra Fusieckiego). Fusiecki na terenie zaboru pruskiego utrzymywał zresztą kontakty nie tylko z Biblioteką Kórnicką, ale z poznańskimi księgarzami: Żupańskim i Józefem Lissnerem oraz Ernestem Wilhelmem Günterem z Leszna, a jako bibliofil kontaktował się ze zbieraczami książek z całego $\mathrm{kraju}^{53}$.

\section{Zakończenie}

Anna Aleksiewicz w artykule omawiającym rolę polskiej książki w kształtowaniu więzi między poszczególnymi zaborami w pierwszej połowie XIX w. ${ }^{54}$ wskazała szereg czynników, które temu sprzyjały, takich jak jedność literatury, pomnikowe dzieła naukowe, rola czasopism, książki emigracyjnej w upowszechnianiu treści zakazanych przez cenzurę państw zaborczych oraz działalność w tym zakresie księgarzy i wydawców krajowych. Zwróciła uwagę na początki ogólnopolskiej rejestracji bibliograficznej. Podkreśliła zasługi różnego rodzaju bibliotek w gromadzeniu i upowszechnianiu dziedzictwa narodowego. Większość z tych czynników zachowała swoje znaczenie w drugiej połowie XIX w. Rola niektórych z nich zmieniła się ze względu na inną sytuację polityczną. Trzeba tu przede wszystkim wskazać wprowadzenie autonomii

51 B. Kosmanowa, Biblioteki skarbnicami polskości w Wielkim Księstwie Poznańskim (do czasów Kulturkampfu), „Przegląd Humanistyczny”1981, t. 25, nr 10-12, s. 30.

52 Cyt. za B. Kosmanowa, Biblioteki skarbnicami..., s. 26.

53 Schmager G., Fusiecki Aleksander Wojciech, [w:] Słownik pracowników książki polskiej, pod red. I. Treichel, Warszawa-Łódź 1972, s. 238-239.

54 A. Majkowska-Aleksiewicz, Rola książki w kształtowaniu więzi międzyzaborowej w pierwszej połowie XIX w., „Acta Universitatis Wratislaviensis. Bibliotekoznawstwo” 1995, [t.] 19, s. 7590. 
galicyjskiej, które przyniosło szereg swobód mających także wpływ na świat książki. Do roli ważnego ośrodka urósł Kraków, nazywany centrum polskości, polskimi Atenami. Dla świata książki istotne znaczenie miało utworzenie tu Akademii Umiejętności, która nie tylko integrowała ludzi nauki ze wszystkich zaborów, lecz także na szeroką skalę prowadziła działalność wydawniczą. Także różnego rodzaju uroczystości patriotyczne, łączące mieszkańców poszczególnych zaborów odgrywały rolę stymulatora ruchu wydawniczego. Natomiast spadło znaczenie Wilna. Szczególnie trudne dla tego miasta były lata represji po upadku powstania styczniowego, kiedy dokonywano licznych rewizji w księgarniach w poszukiwaniu zabronionej literatury, a polski ruch wydawniczy niemal zamarł. Jednakże i tutaj można zauważyć próby upowszechniania polskiej książki z pobudek patriotycznych, czego przykładem była choćby działalność wydawnicza i księgarska Elizy Orzeszkowej ${ }^{55}$.

Podjęty w artykule temat jest bardzo szeroki. Dlatego też wskazałam jedynie przykładowe działania instytucji książki, zmierzające do utrzymania więzi między zaborami. Poszczególne wątki, związane z rolą drukarzy, księgarzy, bibliotek czy samej książki mogą być przedmiotem odrębnych opracowań.

\section{Bibliografia}

Berbelicki W., Dary dla Biblioteki Jagiellońskiej w l. 1868-1904, „Biuletyn Biblioteki Jagiellońskiej" 1959, t. 11, nr 1-2 s. 59-84.

Bieńkowski W., Krakowskie wydawnictwa obchodów kościuszkowskich w 1894 roku, „Studia Bibliologiczne” 1995, t. 9, s. 164-171.

Bieńkowski W., Kraków a Warmia i Mazury w XIX i XX wieku. Kontakty naukowe oraz związki kulturalne, „Rocznik Olsztyński” 1975, t. 11, s. 63-117.

Bieńkowski W., Obchody kościuszkowskie w Krakowie w 1894 roku, [w:] Kraków w powstaniu kościuszkowskim, red. J. M. Małecki, Kraków 1996, s. 83-132.

Bieńkowski W., Wydawnictwa obchodu dwustulecia odsieczy wiedeńskiej w 1883 r. i ich rejestracja bibliograficzna, [w:] Kultura książki w Krakowie doby autonomii galicyjskiej, pod red. M. Kocójowej, Kraków 1991, s. 15-28.

Broda H., Działalność drukarska i bibliofilska Wactawa Anczyca, „Roczniki Biblioteczne” 1979 , t. 23, s. 127-153.

Byczkowska Z., Popularyzacja książek beletrystycznych w czasopismach ludowych Królestwa Polskiego w latach 1866-1898, „Pamiętnik Biblioteki Kórnickiej” 1981, z. 18, s. 123-151.

55 A. Romanowski, Między „mrozem” a ,odwilża”. Polski ruch księgarski i wydawniczy na Litwie i Białorusi w latach 1864-190, [w:] Życie literackie i literatura w Wilnie XIX-XX wieku, pod red. T. Bujnickiego i A. Romanowskiego, Kraków 2000, s. 67. 
Cabaj J., „Jesteśmy i być chcemy”. Z organizacji i statystyki zjazdów międzyzaborowych polskich środowisk medycznych i przyrodniczych, 1869-1914, część 1, „Kwartalnik Historii Nauki i Techniki" 2004, t. 49, nr 3-4, s. 135-156.

Cabaj J., Zjazdy międzyzaborowe polskich środowisk naukowych i społeczno-zawodowych w latach 1969-1914, część 2, „Kwartalnik Historii Nauki i Techniki” 2005, t. 50, nr 1, s. 51-78.

Dippel S., O księgarzach, którzy przeminęli, Wrocław 1976.

Dunin J., Losy książi polskiej w Wilnie XIX-XX wieku a jej sytuacja na terenie Galicji. (Próba ujęcia konfrontatywnego), [w:] Kraków-Lwów. Książki, czasopisma, biblioteki XIX i XX wieku, t. 5, pod red. J. Jarowieckiego, Kraków 2001, s. 35-41.

Epsztein T., Biblioteki wędrowne w dworach ziemiańskich na Lubelszczyźnie w XIX i XX wieku, [w:] Ziemiaństwo na Lubelszczyźnie. Materiały II sesji naukowej zorganizowanej w Muzeum Zamoyskich w Kozłówce 22-24 maja 2002, oprac. R. Maliszewska, Kozłówka 2003, s. 555-561.

Epsztein T., Z piórem i paleta. Zainteresowania intelektualne $i$ artystyczne ziemiaństwa polskiego na Ukrainie w II połowie XIX w., Warszawa 2005.

Fiszer L., Wspomnienia starego ksiegarza, Warszawa 1959.

Foć M., Romanowska M., Jan Konstanty Żupański. Życie i dzieło, Poznań 1996.

Galos A., Tendencje integracyjne $i$ dezintegracyjne na ziemiach polskich $w$ dobie popowstaniowej (do 1914 r.), [w:] Drogi integracji spoleczeństwa w Polsce XIX-XX w., pod red. H. Zielińskiego, Wrocław 1976, s. 9-33.

Gottlieb W., Księgarstwo małopolskie przed wojną światowa, „Przegląd Księgarski” 1933, R. 19, nr 25, s. 187-192.

Gruca A., Działalność wydawnicza drukarń krakowskich w okresie autonomii galicyjskiej, [w:] Ludzie i książki. Studia i szkice bibliologiczno-biograficzne, red. E. Andrysiak, Łódź 2011, s. 135-146.

Gruca A., Wydawnictwa poznańskie w asortymencie księgarni Spółki Wydawniczej Polskiej w Krakowie (1890-1916), [w:] Kultura książki w Krakowie doby autonomii galicyjskiej. Praca zbiorowa, pod red. M. Kocójowej, Wrocław 1991, s. 49-62.

Heska-Kwaśniewicz K., Promocja ksiązki polskiej na łamach „Zarania Ślaskiego” w latach 1907-1912, [w:] Książka polska na Śląsu 1900-1922. Zarys problematyki, pod red. M. Pawłowiczowej, Katowice 1993, s. 91-97.

Kalczyńska M., Drogi rozchodzenia się książki polskiej na Górnym Śląsku na przełomie XIX i XX wieku, „Studia Bibliologiczne” 1998, t. 11, s. 18-30.

Kandulska I., Działalność Jarosława Leitgebera - drukarza, ksiegarza, wydawcy i pisarza ludowego w latach 1873-1914, „Pamiętnik Biblioteki Kórnickiej”, 1979, z. 15, s. 107-136.

Kocójowa M., Geneza księgarni, działalność i exodus z Warszawy Aleksandra Nowoleckiego, „Roczniki Biblioteczne” 1980, R. 24, z. 1, s. 257-319.

Koehlerówna A., Biblioteka Poznańskiego Towarzystwa Przyjaciół Nauk 1857-1957, „Roczniki Historyczne” 1957, R. 23, s. 3 81-430. 
Konopka M., Adam Dominik Bartoszewicz redaktor, księgarz $i$ wydawca lwowski (1838-1886), Kraków 1995.

Korpała J., Dzieje bibliografii w Polsce, Warszawa 1969.

Korpała J., Karol Estreicher [st.] twórca „Bibliografii polskiej”, Wrocław 1980.

Kosmanowa B., Biblioteki polskie w Wielkim Księstwie Poznańskim, Poznań 1982.

Kosmanowa B., Biblioteki skarbnicami polskości w Wielkim Księstwie Poznańskim (do czasów Kulturkampfu), „Przegląd Humanistyczny” 1981, t. 25, nr 10-12, s. 21-37.

Kostecki A., Publikacje importowane na rynku księgarskim zaboru rosyjskiego w latach 1865 1904. Z problemów geografii kontaktów, [w:] Ksiązka i prasa w systemie komunikacji spotecznej. Przeszłość, dzień dzisiejszy, perspektywy, pod red. M. Judy, Lublin 2002, s. 51-59.

Łakociński J., [List do Redakcji], „Przewodnik dla Spraw Drukarsko-Litograficznych” 1889 , t. 1, s. 91.

Majkowska-Aleksiewicz A., Rola książki w kształtowaniu więzi międzyzaborowej w pierwszej połowie XIX w., „Acta Universitatis Wratislaviensis. Bibliotekoznawstwo” 1995, [t.] 19, s. 75-90.

Mężyński A., Biblioteka Kórnicka Jana Działyńskiego, „Pamiętnik Biblioteki Kórnickiej” 1976, z. 12, s. 117-175.

Pater M., Polskie dążenia narodowe na Górnym Ślasku (1891-1914), Wrocław 1998.

Rederowa D., Jabłoński Z., Zarys dziejów Biblioteki PAN w Krakowie w latach 18561956, „Rocznik Biblioteki Polskiej Akademii Nauk w Krakowie” 1957, t. 1, s. 8-46.

Romanowski A., Między „,mrozem” a „odwilża”. Polski ruch księgarski i wydawniczy na Litwie i Białorusi $w$ latach 1864-1890, [w:] Życie literackie i literatura $w$ Wilnie XIX-XX wieku, pod red. T. Bujnickiego i A. Romanowskiego, Kraków 2000, s. 51-96.

Rulikowski M., Ksiegarstwo i czytelnictwo polskie wobec wojny, Warszawa 1915.

Rulikowski M., Księgarstwo polskie w Królestwie w czasie wojny, Warszawa 1918.

Stachowska K., Starania Polskiej Akademii Umiejętności o upowszechnianie własnych nakładów wydawniczych w latach 1873-1952, „Rocznik Biblioteki Polskiej Akademii Nauk w Krakowie" 1969, t. 15, s. 16-87.

Tokarska A., Ksiązki, ludzie, idee. Kontakty kulturalne Górnego Śląska z Krakowem w dobie niewoli narodowej, Katowice 2003.

Wańka D., Krakowski świat książki w „,Gazecie Kaliskiej” (1893-1914), [w:] Kraków Lwów. Książki - czasopisma - biblioteki XIX i XX wieku. T. 2, pod red. H. Kosętki, B. Góry, E. Wójcik, s. 110-120.

Wilk B., Uroczystości patriotyczno-religijne w Krakowie w okresie autonomii galicyjskiej (1860-1914), Kraków 2006.

Zagartowska B., Bibliotekarz [Zygmunt Celichowski], „Pamiętnik Biblioteki Kórnickiej” 1996, z. 24, s. 9-39. 